\title{
PEMANFAATAN EKSTRAK TERSTANDARDISASI DAUN SOM JAWA (Talinum paniculatum (Jacq.) Gaertn) DALAM SEDIAAN KRIM ANTIBAKTERI Staphylococcus aureus
}

\author{
Wahyuning Setyani ${ }^{*}$, Hanny Setyowati ${ }^{2}$, Dewi Ayuningtyas ${ }^{3}$ \\ ${ }^{1}$ Fakultas Farmasi, Universitas Sanata Dharma Yogyakarta, Indonesia \\ ${ }^{2}$ Departemen Penelitian dan Pengembangan, PT. Industri Jamu Borobudur, Semarang, Indonesia \\ ${ }^{3}$ Sekolah Tinggi Ilmu Farmasi Yayasan Pharmasi, Semarang, Indonesia
}

Received April 28, 2016; Accepted May 27, 2016

\begin{abstract}
Infectious diseases have been the leading cause of morbidity and mortality because of the widespread antibacterial resistance due to existing drugs. Thus, the discovery and development of new antimicrobial agents, especially from natural resources is important to promote the human health. This research aimed to examine the antibacterial activity of som jawa (Talinum paniculatum (Jacq.) Gaertn.) standardized extract thus their application into cream. Extraction was done by remaceration method, then followed by phytochemical investigation to obtain the active ingredients inside extract. The result of this research showed that both som jawa standardized extract and their formula cream had antibacterial activity towards Staphylococcus aureus. This formula cream was potential as alternative herbal medicine for skin infection caused by Staphylococcus aureus.
\end{abstract}

Keywords: Som Jawa (Talinum paniculatum (Jacq.) Gaertn), antibacterial, cream

\section{PENDAHULUAN}

Penyakit yang disebabkan oleh infeksi merupakan salah satu permasalahan dalam bidang kesehatan yang dari waktu ke waktu terus berkembang. Salah satu penyebabnya adalah bakteri (Xie et al., 2015). Bakteri patogen lebih berbahaya dan menyebabkan infeksi baik secara sporadik maupun endemik, antara lain Staphylococcus aureus, Escherichia coli, dan Pseudomonas aeruginosa (Djide dan Sartini, 2008).

Staphylococcus aureus merupakan bakteri gram positif yang termasuk flora normal pada kulit (Foster et al., 2014). Staphylococcus aureus dapat menyebabkan penyakit infeksi pada folikel rambut dan kelenjar keringat, bisul, serta infeksi pada luka. Bakteri ini mempunyai kemampuan invasi rendah, terlibat dalam banyak infeksi kulit (Miller et al., 2012). Setiap jaringan yang terinfeksi, biasanya muncul tanda-tanda yang khas seperti peradangan dan pembentukan abses (Zhang et al., 2015)

Meluasnya resistensi bakteri terhadap obatobatan yang ada, mendorong pentingnya penggalian antibakteri baru dari bahan alam. Tanaman obat sangat potensial dikembangkan, namun masih banyak yang belum dibuktikan aktivitasnya secara ilmiah (Hertiani et al., 2003)

Hampir setiap hari semakin banyak saja hasil positif yang dilaporkan oleh pengguna daun dan akar dari som jawa dalam mengobati berbagai penyakit bisul, ASI sedikit, batuk dengan dahak dan darah, radang paru-paru, keringat dingin, diare, banyak kencing, haid tidak teratur, keputihan, dan sebagainya, maka secara empiris daun dan akar som jawa telah terbukti sebagai tanaman obat berkhasiat (Subroto dan Saputro, 2008). Namun, senyawa yang aktif terhadap aktivitas antibakteri belum diketahui.

Sebagai upaya untuk meningkatkan kualitas obat tradisional, proses standardisasi penting dilakukan terhadap ekstrak yang mengandung senyawa aktif. Ekstrak sebagai bahan awal dianalogikan dengan komoditi bahan baku obat yang dengan teknologi fitofarmasi diproses menjadi produk jadi, baik dalam bentuk kapsul, tablet, pil, maupun dalam bentuk sediaan topikal (Pine et al., 2011). Standardisasi ekstrak etanol 
daun som jawa telah dilakukan oleh Suharsanti dan Sulistiyanto (2012) yang menunjukkan bahwa ekstrak telah memenuhi seluruh persyaratan parameter standardisasi.

Penggunaan ekstrak terstandardisasi akan lebih optimal dengan memformulasikannya dalam bentuk sediaan, salah satunya sediaan krim. Sediaan krim merupakan salah satu sediaan farmasi yang digunakan secara topikal untuk pengobatan berbagai penyakit kulit. Krim lebih banyak digunakan karena praktis, lebih mudah digunakan, menimbulkan rasa dingin, mudah dicuci, tidak berlemak, dapat digunakan untuk daerah yang tertutup rambut, memberikan rasa nyaman (tidak iritasi), mudah dibersihkan dari kulit, memungkinkan kontak dengan tempat aplikasi lebih lama, dan tidak lengket seperti salep atau sediaan farmasi lainnya (Sulaiman et al., 2008).

Berdasarkan uraian diatas, dilakukan uji aktivitas ekstrak terstandardisasi daun som jawa kemudian diformulasikan dalam sediaan krim. Harapannya adalah dapat ditemukan obat herbal alternatif untuk pengobatan infeksi bakteri Staphylococcus aureus.

\section{METODE PENELITIAN Alat dan Bahan}

Alat yang digunakan yakni ayakan no. mesh 60 , blender, beaker glass, timbangan digital, cawan porselin, rotary evaporator, bejana kromatografi, pipa kapiler, plat silika GF 254, kertas penjenuh, oven, alat penyemprot penampak bercak, lampu UV $254 \mathrm{~nm}$, pipet tetes, indikator $\mathrm{pH}$, lumpang alu, cawan petri, kawat ose, yellow tip $(100 \mu \mathrm{L})$, micropipette, jangka sorong, autoklaf, oven, inkubator, LAF, cylinder cup, bunsen, tabung reaksi, statif dan klem.

Bahan yang digunakan yaitu ekstrak daun som jawa, etanol teknis $70 \%$, etil asetat teknis, nheksana teknis, air, bakteri Staphylococcus aureus, media MSA (Manittol Salt Agar) merk oxoid, media NA (Nutrient Agar) merk oxoid, media NB (Nutrient Broth) merk oxoid, larutan 1/2 Mc Farland, ampisilin (Phapros), silika Gel $\mathrm{GF}_{254}$, kloroform pa, methanol pa, anisaldehida $-\mathrm{H}_{2} \mathrm{SO}_{4}$, n-butanol pa, asam asetat glasial pa, toluen pa, etil asetat pa , asam stearat, gliserin, $\mathrm{Na}$ tetraborat, trietanolamin, propilenglikol dan tween 80 .

\section{Determinasi Tanaman}

Sampel yang digunakan adalah daun som jawa (Tallinum panicalatum (Jacq.) Gaertn) yang diperoleh dari Lembaga Ilmu Pengetahuan Indonesia (LIPI), Bogor. Teknik sampling yang digunakan adalah sampling secara acak (random sampling).

\section{Ekstraksi}

Metode ekstraksi yang digunakan yaitu remaserasi dengan cara merendam $100 \mathrm{~g}$ serbuk simplisia daun som jawa dengan $300 \mathrm{~mL}$ etanol $70 \%$. Penyarian dilakukan $3 \times 24$ jam dengan penggantian cairan penyari setiap 1 x 24 jam. Setelah 3 hari atau proses ekstraksi berakhir, maserat dikumpulkan dan dipekatkan dengan rotary evaporator dan waterbath sampai diperoleh ekstrak kental. Ekstrak kental diuji bebas etanol yang dilakukan dengan menambahkan asam sulfanilat, $\mathrm{HCl}$, dan larutan $\mathrm{NaNO}_{2}$ ke dalam sejumlah kecil ekstrak albedo buah durian. Campuran tersebut ditambah larutan $\mathrm{NaOH}$ kemudian dipanaskan. Jika ekstrak masih mengandung etanol akan terbentuk warna merah frambos. Cara lain adalah dengan menambahkan asam asetat dan $\mathrm{H}_{2} \mathrm{SO}_{4}$ ke dalam ekstrak kental, kemudian dipanaskan. Jika ekstrak masih mengandung etanol akan terbentuk bau pisang (Schoorl, 1998)

\section{Skrining Fitokimia}

Skrining fitokimia dilakukan terhadap beberapa golongan senyawa, diantaranya:

\section{Flavonoid}

Ekstrak kental 0,5 g dilarutkan dalam etanol kemudian dimasukkan dalam tabung reaksi. Serbuk $\mathrm{Mg}$ dan $\mathrm{HCl}$ pekat ditambahkan ke dalam tabung reaksi. Hasil tersebut ditambah amil alkohol, dikocok dengan kuat dan dibiarkan hingga memisah. Bila terdapat flavonoid maka akan terbentuk warna merah atau coklat pada lapisan amil alkohol (Depkes RI, 1995).

\section{Saponin}

Ekstrak kental 0,5 g dicampur dengan $10 \mathrm{~mL}$ air panas kemudian didinginkan dan dikocok hingga muncul buih. Larutan didiamkan selama 2 
menit, kemudian diteteskan $\mathrm{HCl} 2 \mathrm{~N}$. Bila terdapat senyawa saponin dalam ekstrak maka akan terbentuk buih mantap selama 10 menit (Depkes RI, 1995).

\section{Tanin}

Ekstrak kental 1 (satu) g dicampur dengan 10 $\mathrm{mL}$ aquadest panas dan dipanaskan kurang lebih 1 jam. Larutan kemudian didinginkan dan disaring dengan kertas saring. Filtrat yang diperoleh dibagi menjadi dua bagian. Filtrat pertama ditambahkan 5 mL larutan $\mathrm{FeCl}_{3} 1 \%$, jika terbentuk warna biru tua atau hijau kehitaman maka hal itu menunjukkan adanya senyawa golongan tanin. Filtrat yang kedua ditambahkan $15 \mathrm{~mL}$ pereaksi Stiasny (formaldehid $30 \%: \mathrm{HCl}$ pekat $=2: 1$ ), lalu dipanaskan di atas penangas air sambil digoyang-goyangkan. Jika terbentuk endapan warna merah muda menunjukkan adanya tanin katekuat. Endapan disaring, filtrat dijenuhkan dengan serbuk natrium asetat, ditambahkan beberapa tetes larutan $\mathrm{FeCl}_{3} 1 \%$, jika terbentuk warna biru tinta maka menunjukkan adanya tanin galat (Depkes RI, 1995).

\section{Alkaloid}

Ekstrak kental sebanyak 0,5 g dicampur dengan $1 \mathrm{~mL} \mathrm{HCl} 2 \mathrm{~N}$ dan $9 \mathrm{~mL}$ aquadest panas. Larutan dipanaskan selama 2 menit, kemudian didinginkan dan disaring lalu filtratnya dibagi dua. Filtrat pertama diteteskan pada kertas saring kemudian disemprot dengan pereaksi Dragendorf, sisanya dimasukkan dalam tabung reaksi dan ditambahkan pereaksi Dragendorf. Sampel positif terdapat alkaloid bila terbentuk warna merah atau jingga (Majumdar, 2005).

\section{Kuinon}

Ekstrak kental 0,5 g dicampur dengan $10 \mathrm{~mL}$ air didihkan 15 menit, saring, filtrat yang diperoleh ditambahkan $\mathrm{NaOH} 1 \mathrm{~N}$. Terbentuknya warna merah menunjukkan adanya senyawa golongan kuinon. Sampel positif mengandung kuinon bila terbentuk warna merah (Majumdar, 2005).

\section{Kromatografi Lapis Tipis-Densitometri}

Ekstrak dilarutkan dengan etanol $96 \%$ dibuat konsentrasi $20 \%$ atau $20 \mathrm{mg} / \mathrm{mL}$.
Sistem KLT untuk uji flavonoid adalah sebagai berikut:

Volume cuplikan : $5 \mu \mathrm{L}$

Fase diam

Fase gerak

silika gel GF 254 dengan jarak pengembangan $8 \mathrm{~cm}$

n-butanol: asam asetat : air $(4: 1: 5)$

Ditotolkan cuplikan ke fase diam yang telah diberi batas elusi, masukkan ke dalam chamber berisi eluen yang telah dijenuhkan. Elusi dihentikan saat mencapai batas elusi. Diamati noda dibawah sinar UV $254 \mathrm{~nm}$ dan $366 \mathrm{~nm}$ (Narwade et al., 2012).

\section{Uji aktivitas antibakteri}

Media NA (Nutrient Agar) dimasukkan dalam cawan petri steril sebanyak $10 \mathrm{~mL}$, dan dibiarkan memadat. Setelah media memadat, lapisan dasar tersebut diberi cylinder cup kemudian dimasukkan media NA sebanyak $10 \mathrm{~mL}$ yang sudah diberi suspensi bakteri Staphylococcus aureus $(5 \mu \mathrm{L}$ bakteri / $20 \mathrm{~mL}$ media) dibiarkan hingga memadat, setelah itu cylinder cup dicabut dari media. Pada masing-masing cylinder cup diberi ekstrak dengan konsentrasi 30\%, 40\%, 50\%, 60\%, 70\%, kontrol positif (ampisilin 1\%), dan kontrol negatif (DMSO) dengan replikasi empat kali. Cawan petri tersebut kemudian diinkubasi pada suhu $37^{\circ} \mathrm{C}$ selama 24 jam. Adanya diameter zona hambat disekeliling sumuran menunjukkan adanya aktivitas antibakteri dan dilakukan pengukuran dengan jangka sorong.

\section{Pembuatan krim}

Formulasi basis krim terdiri atas asam stearat, gliserin, trietanolamin (TEA), dan aquadest.

$\begin{array}{lc}\text { R/ Asam stearat } & 142 \\ \text { Glycerin } & 100 \\ \text { Triaethanolamin } & 10 \\ \text { Aquadest } & 750\end{array}$

Pembuatan basis krim dilakukan dengan menimbang asam stearat dan gliserin untuk dilelehkan diatas penangas air. TEA dan aquadest dicampur, kemudian dimasukkan dalam lelehan campuran pertama. Dilakukan pengadukan untuk mendapatkan basis krim yang homogen. Ekstrak daun som jawa ditambahkan sedikit demi sedikit sambil diaduk hingga terbentuk sediaan krim yang siap diuji aktivitas antibakteri Staphylococcus 
aureus. Pengujian aktivitas krim menggunakan metode yang sama dengan pengujian aktivitas ekstrak terstandardisasi daun som jawa.

\section{Analisa Data}

Data hasil uji aktivitas antibakteri dianalisis menggunakan ANOVA satu jalan yang membandingkan aktivitas antar konsentrasi ekstrak serta aktivitas ekstrak setelah diformulasikan dalam sediaan krim.

\section{HASIL DAN PEMBAHASAN}

Ekstraksi daun som jawa menghasilkan rendemen $17,12 \%$ dan ekstrak sudah bebas etanol dengan tidak terbentuk warna merah maupun bau pisang (Schoorl, 1998), seperti ditunjukkan pada Gambar 1.

Skrining fitokimia menunjukkan bahwa ekstrak mengandung senyawa flavonoid, saponin, tanin, alkaloid, dan kuinon (Tabel 1). Pola spektrum serapan senyawa flavonoid menegaskan hasil uji kandungan senyawa aktif dimana ekstrak mengandung flavonoid dengan nilai Rf sebesar 0,69 pada panjang gelombang $345 \mathrm{~nm}$. Hasil pola kromatogram senyawa flavonoid ditampilkan pada Gambar 2.

Uji aktivitas antibakteri ekstrak terstandardisasi daun som jawa dilakukan untuk memastikan bahwa kandungan senyawa aktif dalam ekstrak memiliki kemampuan menghambat pertumbuhan bakteri Staphylococcus aureus serta menentukan konsentrasi ekstrak dalam sediaan krim. Hasil uji aktivitas antibakteri antar konsentrasi ditunjukkan pada Gambar 3 dan grafik diameter zona hambat ekstrak ditampilkan pada Gambar 4.

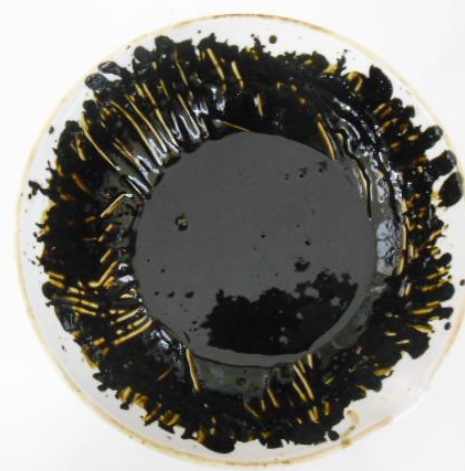

Gambar 1. Ekstrak daun som jawa

Tabel 1. Hasil skrining fitokimia ekstrak daun som jawa

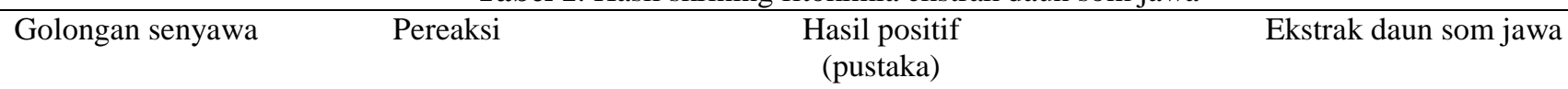

\begin{tabular}{|c|c|c|c|}
\hline Flavonoid & $\begin{array}{l}\text { Serbuk } \mathrm{Mg}+\mathrm{HCl} \mathrm{p}+ \\
\quad \text { amil alkohol }\end{array}$ & $\begin{array}{l}\text { Larutan bewarna pada lapisan amyl } \\
\text { alkohol, warna merah, kuning, jingga } \\
\text { (Depkes RI, 1995) }\end{array}$ & $\begin{array}{c}(+) \\
\begin{array}{c}\text { Warna merah pada lapisan amil } \\
\text { alkohol }\end{array} \\
\end{array}$ \\
\hline Alkaloid & $\begin{array}{c}\mathrm{HCl}+\text { Dragendorff/ } \\
\text { Mayer }\end{array}$ & $\begin{array}{l}\text { Endapan merah/ putih (Depkes RI, } \\
1995)\end{array}$ & $\begin{array}{c}(+) \\
\text { Endapan merah (reagen Dragendorff) } \\
(+) \\
\text { Endapan putih (reagen Mayer) }\end{array}$ \\
\hline Saponin & Dikocok $+\mathrm{HCl} 2 \mathrm{~N}$ & Busa stabil (Depkes RI, 1995) & $\begin{array}{c}(+) \\
\text { Busa stabil }\end{array}$ \\
\hline Tanin & $+\mathrm{FeCl}_{3} 1 \%$ & $\begin{array}{l}\text { Warna biru kehitaman (Majumdar, } \\
\text { 2005) }\end{array}$ & $\begin{array}{c}(+) \\
\text { Biru kehitaman }\end{array}$ \\
\hline Kuinon & $\mathrm{NaOH} 1 \mathrm{~N}$ & Warna merah (Majumdar, 2005) & $\begin{array}{c}(+) \\
\text { Warna merah }\end{array}$ \\
\hline
\end{tabular}




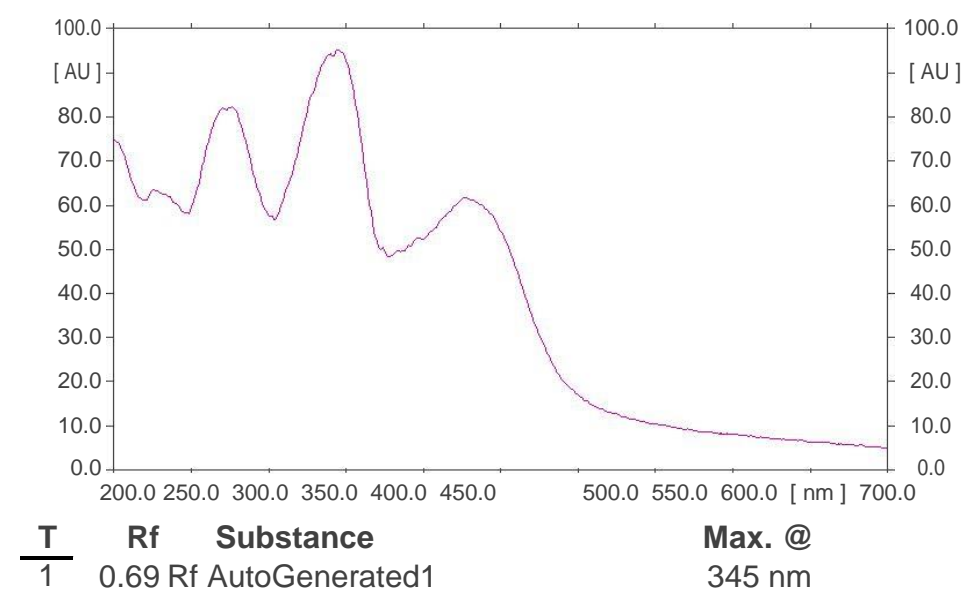

Gambar 2. Pola spektrum serapan senyawa flavonoid pada Rf 0,69
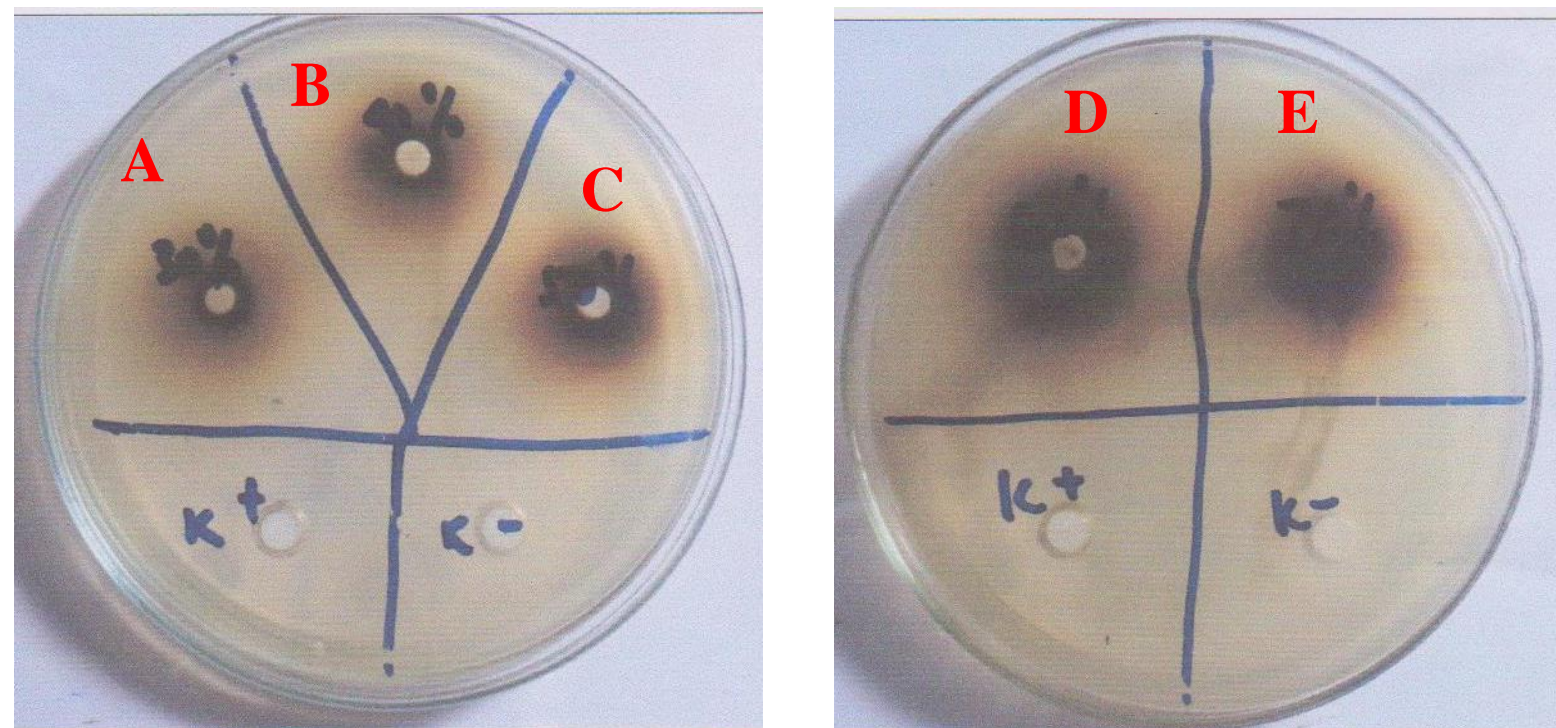

Gambar 3. Hasil uji aktivitas antibakteri. Keterangan: A: ekstrak terstandardisasi konsentrasi 30\%; B: ekstrak terstandardisasi konsentrasi 40\%; C: ekstrak terstandardisasi konsentrasi 50\%, D: ekstrak terstandardisasi konsentrasi 60\%; E: ekstrak terstandardisasi konsentrasi 70\%; K+: ampisilin 1\%; K-: DMSO

Berdasarkan Gambar 4 dapat diamati bahwa konsentrasi ekstrak $70 \%$ memiliki diameter zona hambat terbesar karena kandungan senyawa aktif yang lebih banyak dibandingkan konsentrasi lainnya sehingga meningkatkan kemampuan dalam menghambat pertumbuhan bakteri Staphylococcus aureus. Diameter zona hambat dari seluruh konsentrasi berada pada rentang 1-2 $\mathrm{cm}$ atau 10-20 mm yang termasuk dalam kategori kuat (Davis et al., 1971). Analisis dengan ANOVA satu jalan menunjukkan bahwa antar konsentrasi ekstrak berbeda signifikan sehingga digunakan konsentrasi
$70 \%$ dengan diameter zona hambat terbesar sebagai konsentrasi optimal untuk diformulasikan dalam sediaan krim.

Aktivitas antibakteri dari ekstrak berasal dari kandungan senyawa fitokimia. Flavonoid bekerja dengan cara membentuk senyawa kompleks dengan protein ekstraseluler yang mengganggu integritas membran sel bakteri (Kumar et al., 2013). Alkaloid berfungsi sebagai antibakteri dengan cara mengganggu penyusun peptidoglikan pada sel bakteri, sehingga lapisan dinding sel tidak terbentuk secara utuh dan menyebabkan kematian 
sel tersebut (Cushnie et al., 2014). Saponin mempunyai sifat seperti sabun yang merupakan senyawa aktif permukaan yang kuat, sehingga dapat menurunkan tegangan permukaan. Diabsorbsinya saponin pada permukaan sel akan mengakibatkan kerusakan membran sel dengan naiknya permeabilitas membran atau kebocoran sel sehingga menyebabkan kematian sel karena hilangnya bahanbahan esensial sel (Netala et al., 2014). Aktivitas antibakteri tanin berdasarkan kemampuannya mengkerutkan dinding sel atau membran sel sehingga mengganggu permeabilitas sel bakteri. Terganggunya permeabilitas sel mengakibatkan sel tidak dapat melakukan aktivitas hidup sehingga pertumbuhannya terhambat atau bahkan mati. Selain itu tanin juga memiliki daya antibakteri dengan cara mempresipitasi protein, karena mempunyai efek yang sama dengan fenolik (Courtney et al., 2015).

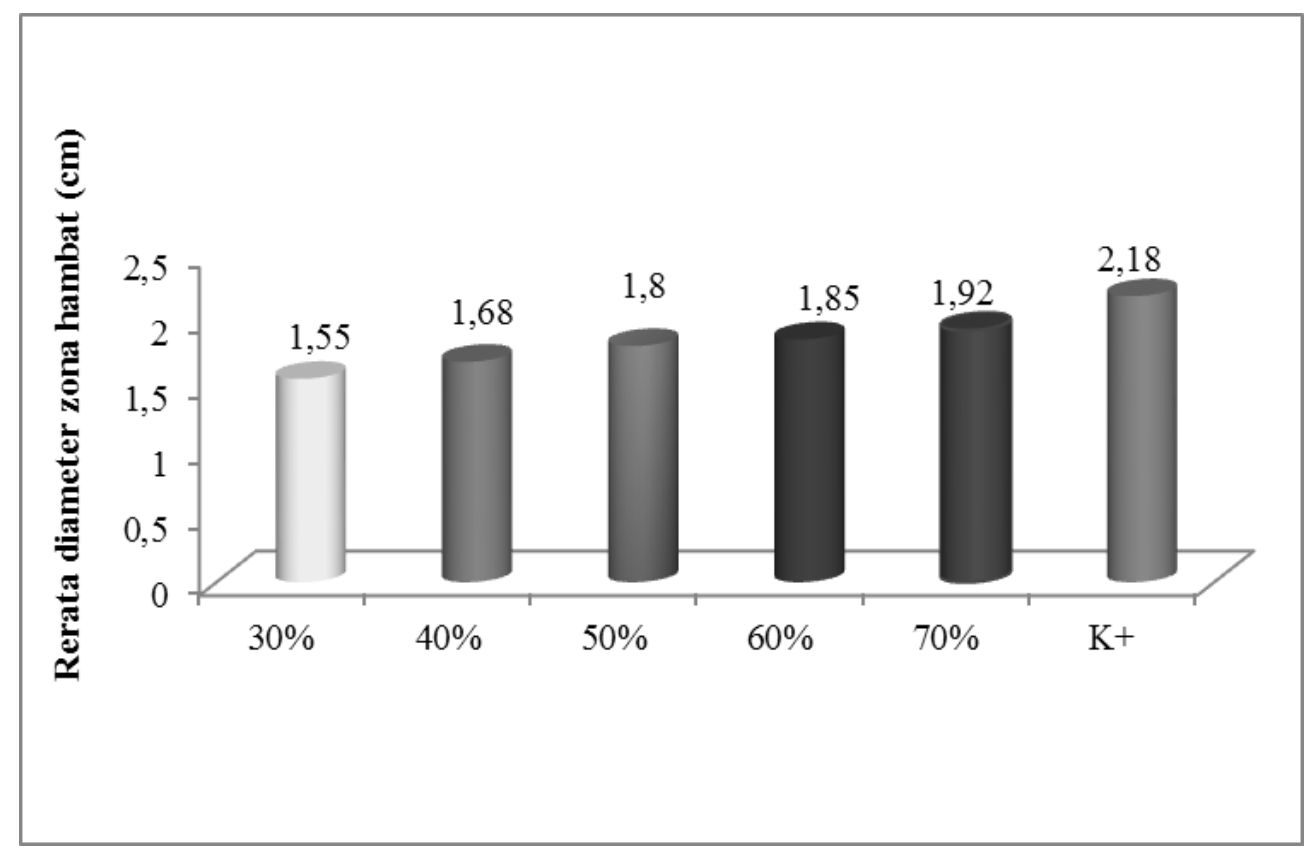

Gambar 4. Grafik diameter zona hambat ekstrak

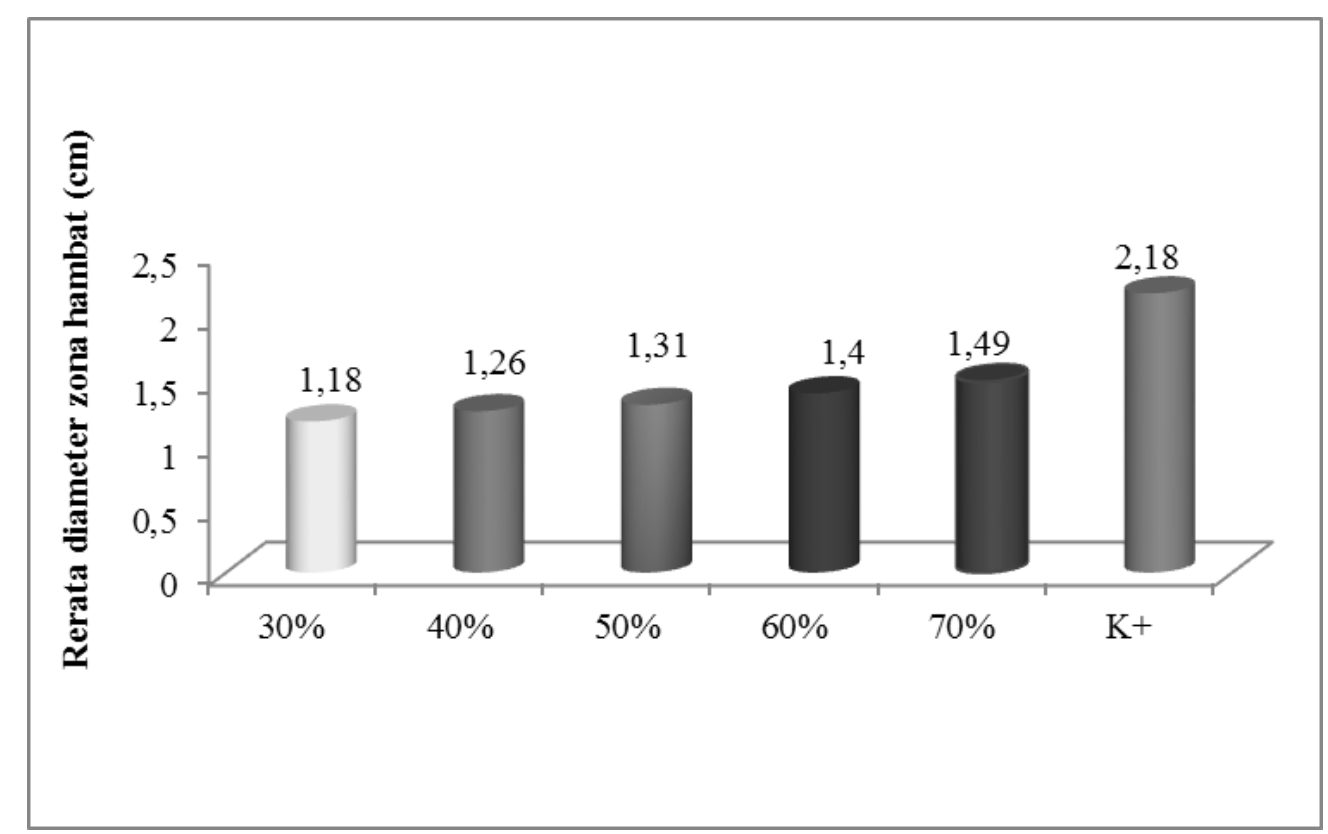

Gambar 5. Grafik diameter zona hambat krim 
Ekstrak yang diformulasikan dalam sediaan krim juga memiliki aktivitas antibakteri, meskipun terjadi penurunan diameter zona hambat jika dibandingkan dengan uji aktivitas antibakteri dari ekstrak (Gambar 5). Hal ini disebabkan fakta bahwa pelepasan senyawa aktif dari sediaan dipengaruhi oleh beberapa faktor yaitu afinitas senyawa terlepas dari basis, kelarutan zat aktif, dan viskositas sediaan itu sendiri (Barry, 1983). Meskipun demikian, sediaan krim yang mengandung ekstrak terstandardisasi daun som jawa mampu menghambat pertumbuhan bakteri Staphylococcus aureus dan lebih acceptable digunakan untuk pengobatan infeksi kulit.

\section{KESIMPULAN}

Ekstrak terstandardisasi daun som jawa mengandung senyawa flavonoid. tanin, saponin, alkaloid, dan kuinon. Senyawa aktif tersebut memiliki efek sinergis dalam menghambat pertumbuhan bakteri Staphylococcus aureus, baik dalam bentuk ekstrak maupun setelah diformulasikan dalam sediaan krim. Sediaan farmasi ini dapat menjadi obat herbal alternatif untuk mengatasi infeksi kulit akibat bakteri Staphylococcus aureus.

\section{DAFTAR PUSTAKA}

Barry, B.W., 1983. Dermatological Formulation Percutaneous Absorpsion. Volume 18. New York: Marcel Dekker, Inc, 49-67.

Courtney, R., Sirdaarta, J., Matthews, B., Cock, I.E., 2015. Tannin components and inhibitory activity of Kakadu plum leaf extracts against microbial triggers of autoimmune inflammatory diseases. Pharmacognosy Journal, 7 (1), 18-31.

Cushnie, T.T., Cushnie, B., Lamb, A.J., 2014. Alkaloids: an overview of their antibacterial, antibiotic-enhancing and antivirulence activities. International Journal of Antimicrobial Agents, 44 (5), 377-386.

Davis, W.W. dan Stout, T.R., 1971. Disc plate method of microbiological antibiotic assay. Applied Microbiology, 22 (4), 659-665.
Depkes RI, 1995. Materia Medika Indonesia Jilid VI, Jakarta: Departemen Kesehatan Republik Indonesia.

Djide dan Sartini, 2008. Dasar-Dasar Mikrobiologi Farmasi. Makasar: Lephas.

Foster, T.J., Geoghegan, J.A., Ganesh, V.K., Höök, M., 2014. Adhesion, invasion and evasion: the many functions of the surface proteins of Staphylococcus aureus. Nature Reviews Microbiology, 12 (1), 49-62.

Hertiani, T., Palupi, I.S., Sanliferianti, dan Nurwindasari, H.D., 2003. Uji potensi antimikroba terhadap $S$. aureus, E. coli, Shigella dysentriae, dan Candida albicans dari beberapa tanaman obat tradisional untuk penyakit infeksi. Pharmacon, 4 (2). UMS, Surakarta.

Kumar, S., Pandey, A.K., 2013. Chemistry and biological activities of flavonoids: an overview. The Scientific World Journal, 29.

Majumdar, M., 2005. Evaluation of Tectona grandis leaves for wound healing activity. Thesis, Departement of Pharmacology, Krupadhini College of Pharmacy, Bangalore.

Miller, L.G., Eells, S.J., Taylor, A.R., David, M.Z., Ortiz, N., Zychowski, D., Kumar, N., Cruz, D., Boyle-Vavra, S., dan Daum, R.S., 2012. Staphylococcus aureus colonization among household contacts of patients with skin infections: risk factors, strain discordance, and complex ecology. Clinical Infectious Diseases, 54 (11), 1523-1558.

Narwade, V.T., Waghmare, A.A., dan Vaidya, A.L., 2012. Detection of minor flavonoids from Tragia plukenetii A. R. Smith. International Multidisciplinary Research Journal, 2 (3), 51-52.

Netala, V.R., Ghosh, S.B., Bobbu, P., Anitha, D., dan Tartte, V., 2014. Triterpenoid saponins: a review on biosynthesis, applications and mechanism of their action. International Journal of Pharmacy and Pharmaceutical Sciences, 7 (1).

Pine, A.T., Alam, G., dan Attamim, F., 2011. Standardisasi mutu ekstrak daun gedi 
(Abelmoschus manihot (L.) Medik) dan uji efek antioksidan dengan metode DPPH. Tesis, Pascasarjana Fakultas Farmasi Universitas Hasanuddin Makasar.

Schoorl, 1988. Materi Pelengkap Kemurnian Cara Pemisahan Obat. Yogyakarta: Gajah Mada University Press.

Subroto A, dan Saputro H., 2008. Gempur Penyakit dengan Sarang Semut, Jakarta: Penebar Swadaya

Suharsanti, R., Sulistiyanto, F.X., 2012. Standarisasi ekstrak daun som jawa (Talinum paniculatum (Jacq) Gaertn) untuk menjamin mutu penggunaan sebagai obat herbal. In: Prosiding Seminar Nasional "Perkembangan Terbaru Pemanfaatan Herbal Sebagai Agen
Kemopreventif Pada Terapi Kanker”, Fakultas Farmasi Universitas Wahid Hasyim, Semarang.

Sulaiman, T.N., 2008. Teknologi dan Formulasi Sediaan Semi Padat. Yogyakarta: UGM Press

Xie, Y., Yang, W., Tang, F., Chen, X., Ren, L., 2015. Antibacterial Activities of Flavonoids: structure-activity relationship and mechanism. Current Medicinal Chemistry, 22 (1), 132-181.

Zhang, L.J., Guerrero-Juarez, C.F., Hata, T., Bapat, S.P., Ramos, R., Plikus, M.V., Gallo, R.L., 2015. Dermal adipocytes protect against invasive Staphylococcus aureus skin infection. Science, 347 (6217), 67-71. 